\title{
How Religion Frames Health Norms: A Structural Theory Approach
}

\author{
Elias Mpofu ${ }^{1,2,3}$ \\ 1 Rehabilitation and Health Services Department, University of North Texas, 1155 Union Circle, \#311456, \\ Denton TX 76205 USA; Elias.Mpofu@unt.edu \\ 2 Rehabilitation Counselling, University of Sydney, Lidcombe, NSW 2141, Australia \\ 3 Educational and Inclusive Education, University of Johannesburg, Auckland, Johannesburg, South Africa
}

Received: 18 January 2018; Accepted: 4 April 2018; Published: 9 April 2018

\begin{abstract}
Religious communities influence health-related behaviors of adherents in important ways for public health promotion. Questions remain about the processes involved and resultant health promotion actions of the religious adherents. This study applied a structural theory analysis to understand the ways by which religious adherents adopt and enact health norms. Structural theory proposes systemic influences on behavioral predispositions at the latent, interpretive, and elective levels. Latent influences on health norms occur through a process of social mediation, predisposing the religious adherents to impute faith-aligned meanings to their health norms. Religious adherents also might adopt interpretation to guide their health norms in those grey areas in which faith-based guidelines are not apparent or open to contestation. Moreover, religious adherents may elect to construct health norms combining faith-aligned and prevailing secular community standards. Public health promotion with religious adherents should address their faith-aligned health beliefs while also addressing their evolving personal health norms.
\end{abstract}

Keywords: health; religion adherents; knowledge values; secular community; faith-based; interpretive norms

\section{Introduction}

Religious communities have significant followings throughout the world, and their teachings are important conduits for health promotion among the adherents (Duff and Buckingham 2015; Gunderson and Cochrane 2012; Levin 2013; Olivier 2015). In their diversity, religious communities bind adherents to beliefs in a higher spiritual power or God (Graham and Haidt 2010; Wesselmann et al. 2016). Religious communities also hold the members to expectations to live by the faith's precept teachings (Ha et al. 2014; Karam et al. 2015). Yet, faith factors are minimal in public health discourses, and the processes or roles of religious communities in public health programming are poorly understood (Ha et al. 2014; Karam et al. 2015; Tomkins et al. 2015). Moreover, it is unclear how religious adherents construct, adopt, and enact their personal health norms in a secular world. Health norms guide activities (i.e., a comprehensive set of actions) and actions (i.e., specific behaviours) people take to maintain, restore, or augment their well-being. Health norms often are the targets for public health promotion interventions (Hoffman 2006). Implicitly held health norms influence health behaviour through the attitudes and activities they underpin (Pender and Pender 1985). This article proposes likely ways by which religious adherents acquire, enact and evolve faith-aligned health norms important for public health promotion.

This article begins with the premise that religious communities prime the adherents to prioritize certain ways of knowing rather than alternative or competing ones (McCullough and Willoughby 2009). For that reason, religious adherents may believe to derive health benefits from their affiliation compared to others who are unaffiliated (Hill et al. 2006; Muramoto 1999; Pietkiewicz and Bachryj 2016; 
Tomkins et al. 2015). For instance, the research evidence is strong to suggest that religion adherents across faith traditions (Christians, Jews, Muslims) are less likely to drink, smoke, or engage in gambling compared to the general public (Hill et al. 2006; Islam and Johnson 2003). Moreover, religious adherents have superior mental health compared to the general public (Benjamins et al. 2006; Graham and Haidt 2010; Ray 2009). Religious adherents likely attribute their healthy life-styles to obligatory activities to a higher spiritual power (Muramoto 1999; Pargament et al. 2004; Park 2005; Ray 2009). They also may believe to be gifted with good health by a higher spiritual authority (Clements and Ermakova 2012), which also provides for healing from debilitating illness (Koenig et al. 2001; Kremer et al. 2014; McCullough and Willoughby 2009).

This propositional review article applies structural theory analysis to examine the adoption, enactment and construction of health norms by religious adherents. First, the article provides a brief overview of structural theory to background subsequent application to the construction of health norms with religion adherence. Second, the article proposes socially mediated processes by which religious adherents likely acquire and express their health norms. Third, this article proposes a prospective heuristic model for understanding the diversity of health norms with religion adherence, including their private framing. Finally, the review considers implications for ways in which religious adherents might respond to public health promotion messages aimed to influence their health norms.

This article aims to map the processes by which religious communities guide adherents in their health norms. In doing so, the article explains how religious adherents might personalize their health norms taking into account prevailing secular norms and presenting health needs. In addition, the article proposes how religious adherents may result with diversity in personal health norms from their efforts to resolve contradictions between religious, secular and/or personal health values. Understanding the processes involved in faith-to-health activities and actions is important to public health interventions with religious communities.

\section{The Structural Mediation of Health Norms with Religion Following}

Structural theory (Brenner 2001; Karmon 2007) proposes that what a social collective (e.g., religious community) considers valid knowledge (epistemological foundations), and believes to exist or to be possible (ontological beliefs), influences the member actions through collective learning. The collective learning, which occurs through shared organization narratives, explains and justifies both the historical and contemporary institutional knowledge values (Brenner 2001). The organization narratives "do not simply inform the ... members about the values, practices, and traditions to which their organization is committed, rather, they help to constitute the organizational consciousness of social actors by articulating and embodying a particular reality, and subordinating or devaluing other modes of "organization rationality" (Mumby 1987, p. 231) [emphasis in the original]. Priming of the collective teaching for present social activity requires application of the historical learning. As organization followers adopt the shared narratives of their social collective, they become selectively receptive to institution supported knowledge values and ways of knowing, subordinating alternative, valid understandings (Roth and Lee 2007).

Religious communities are social collectives of adherents to faith teachings. The faith teachings have embedded controlling influences that prime adherents to prioritize certain practices rather than alternative or competing ones (Brenner 2001). Specifically, what a religious community endorses as valid knowledge influences the adherents' actions towards their health and well-being (Park 2005; Mpofu et al. 2011). Each religious community's teachings define the appropriate follower activities and actions consistent with its values (Karmon 2007). Adherents of a religion may not be consciously aware of faith teaching influences on their activities and actions (Tomkins et al. 2015; Brenner 2001; Mpofu et al. 2011), rather, they may perceive to be expressing their religious community identity only (Graham and Haidt 2010; McCullough and Willoughby 2009). Thus, the collective bonding to faith-aligned values results from immersion in the religious practices of their affiliation community (Stetsenko and Arievitch 2004). 
In the context of health promotion, individuals might seek to enact activities (e.g., health maintenance and promotion) and actions (e.g., treatment, restorative, curative, preventive) for wellbeing. For example, actions to restore, augment and maintain health are part of activities aimed at healthy functioning (Hoffman 2006). In general, health activities and actions closely reflect health norms by which they are directed.

Religious communities direct the specific actions and activities for health through a process of social mediation of faith-aligned health values (Olivier 2015). This social mediation process preconditions adherents to identify with religious community culture and its specific, priority activities and actions for health. In this connection, religious communities in their social rules and communication tools influence the health norms of their followers at three levels: latent, interpretive, and elective.

\section{Latent Faith Aligned Health Norms}

As previously noted, religious community teachings have latent or implicit social influences on adherents (Gunderson and Cochrane 2012). These faith-aligned teachings bind the adherents to a religious identity (Ghaly 2012; Ha et al. 2014; Karam et al. 2015; Masters and Spielmans 2007). By definition, a religious identity requires adherence to the faith teachings (Cohen et al. 2005; Muramoto 1999; Skitka et al. 2005). In other words, a religious identity is a latent instrument obliging the adherents to faith-aligned practices for the collective reputation of the membership (Mumby 1987). By implication, the behaviours of religious adherents express underlying faith-aligned values which also guide them in their health choices. With religion affiliation, faith-based precepts likely predetermine priority health activities and actions, within the implicit rules of the religious community at three levels: normative, coercive and mimetic (see Figure 1).

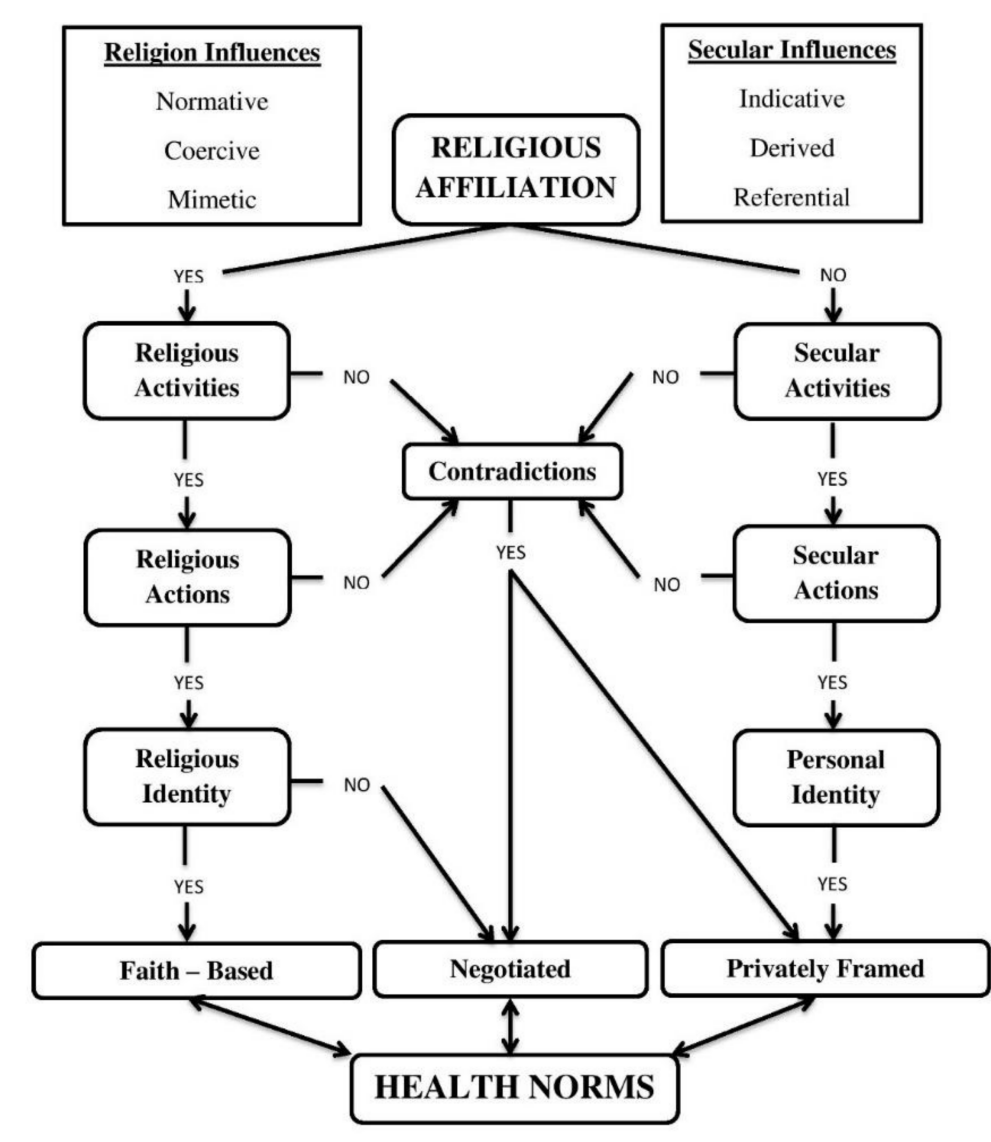

Figure 1. Heuristic Model on Religion Environment Effects on the Framing of Health Norms by Followers. 
Normative rules are those the religious adherents acquire from participating in typical faith community activities or its "how we do business" climate (Jackson and Bergeman 2011). Coercive rules are those obligatory teachings religious adherents must adhere to in order to maintain their religion identity (Ha et al. 2014; Karam et al. 2015). Mimetic rules are those by which religious adherents model their actions after those of others of the same faith (Mpofu et al. 2011).

\subsection{Normative Rule Adherence Effects}

Normative rule influences are rooted in religion-supported teachings about activities and actions aligned with the specific faith teaching. For instance, one religious community might subscribe to the belief that both health and wellbeing are gifted (implying divine ordination) rather than achieved (implying individual volition). Another religious community might teach a health view in which poor health reflects retribution by a higher spiritual force for transgressions. Either of these health norming values would have consequences for what religious adherents believe to explain, promote and sustain their health and wellbeing.

Gifted health statuses. Members of a religious community with a belief in a health gifting God might hold to flourishing health norms, in which they attribute their wellbeing to a benevolent God who takes care of their health-related needs (Ghaly 2012). Adherents to a religion also may believe to be protected by a gracious God who allows only as much suffering as they can handle (Ghaly 2012). Moreover, religious adherents with a health gifting view of God also might adopt or enact healthy life-styles in respect of their higher spiritual authority (Hill et al. 2006; Islam and Johnson 2003). In other words, religious adherents with a gifted view of health may attribute their wellbeing to rewards by a higher spiritual authority, including having the choice to live healthy, and to seek to utilize appropriate health support services (Jackson and Bergeman 2011).

Retribution health statuses. A religious community with a belief in punishing or vengeful God might hold followers to puritanical health norms. For instance, religious adherents with a punishing God belief might attribute their poorer health to a bad relationship with their higher spiritual authority (Chopra 2012; Cuperman 2010; Shariff and Norenzayan 2011). Religious adherents with a vengeful view of God also might self-blame for their diseased corporeal body, perceiving it as an object of pain and suffering with spiritual defilement. Consequently, religious adherents with a punishing view of God may be less inclined to seek care from public health services, believing to have wronged their higher spiritual force for which they are paying with penance suffering.

Religious adherents might adopt various positions along the continuum of gracious health gifting and penance suffering. For example, the activity of prayer may serve as penance or as grateful supplication to a higher spiritual authority. Thus, while the particular normative faith practices (activities and actions) for health might be similar across religions, doctrinal emphasis differences may determine the significance of a particular faith-precept practice.

\subsection{Coercive Rule Adherence}

Coercive rule adherence is when religious adherents carry-out obligatory activities and actions aligned to their faith beliefs. As an example, coercive rule adherence is when religious community adherents adopt faith-aligned health norms for which there is no objective evidence. In such instances, adherents to a religion may oblige to discounting use of evidence-based, secular health services (Johnson et al. 2015; Pietkiewicz and Bachryj 2016; Stetsenko and Arievitch 2004), including denial to use lifesaving maternal health services (Antai et al. 2009) or lifesaving medical treatments such as blood and organ donation (Ha et al. 2014; Hawkins and Gillett 2015). In fact, religious adherents with coercive rule compliance may choose not to utilize primary health care services for treatable, if not curable health conditions (Masters and Spielmans 2007; Wang and Wang 2010). 


\subsection{Mimetic Rule Adherence}

Mimetic rule adherence is when religious adherents seek to align their health promotion activities and actions to those of other followers. In doing so, religious adherents may have personal motives for engaging in an activity (Bryan et al. 2016; Regnerus 2003). For instance, religious adherents may comply with mimetic rules for the personal motive to maintain and enhance social affiliation with same faith others (Kuuti 1996; Mpofu et al. 2011; Sherman and Gorkin 1980). Allport's (Allport and Michael 1967) proposition on extrinsic religiosity orientation is an instance of mimetic faith precept adherence. According to Allport, religious adherents seek self-enhancement through their affiliation with other adherents of the same faith. By implication, good adherence of a religious community would include adoption of heath norms similar to those of fellow adherents (Ha et al. 2014; Karam et al. 2015).

Most of the religious adherents utilize public health services at some level. They may consume public health services in the context of their secular community affiliations (by geography, neighbourhood, education, and social class), their knowledge of public health care services available in their community, and apparent need for the services (Andersen 2008; Roth and Lee 2007). This makes for a transactional process in which religious adherents adopt interpretive health norms to negotiate their utilization of public health services premised on secular health values.

\section{Interpretive Health Norms}

Religious adherents may result with interpretive health norms from resolving contradictions between religious community and secular community health standards (Kline 2011; Roth and Lee 2007). In their adoption of interpretive health norms, religious adherents may be motivated to reconcile their religion and secular community health norms for the benefit to optimize their health service options (Roth and Lee 2007). Religious adherents also may adopt interpretive health norms from the need to resolve psycho-behavioural dissonance from following contradictory religion teachings to which they adhere. For instance, a religion teaching precept to sanction followers who access curative public health services may contradict the intent of their religious teachings on the sanctity of human life (Karam et al. 2015; Mpofu et al. 2011; Tomkins et al. 2015).

Interpretive health norms also may result from seeking to resolve contradictions between competing religious health values and personal health values. In this case, adherents of a religion might choose personal or private health norms to direct their health service choices. As an example, gender reassignment surgery needs by a transgender person may not be recognized by his or her faith community or by the public health services. That being the case, the transgender person may seek to access gender reassignment surgery from private health care providers networked with the gender-nonconforming community. In seeking to resolve contradictions within and between faith-supported and secular health value systems, religious adherents have recourse to three levels of health norms: evidence-informed (indicative), practice-informed (derived), and community standard (reference) health norms (see Figure 1).

Evidence-informed health norms. Evidence-informed health norms are science driven, representing the current best health standards at both the individual and community levels (Mpofu et al. 2015). However, at the extremes of religion and secular health values influences, there may be mutual dis-valuation of evidential claims in which religious adherents choose to disregard proven public health standards for religion-aligned standards. As an example, some religion-aligned health norms have resulted with child fatalities from denial of proven vaccinations (Asser and Swan 1998).

Derived health norms. Derived health norms are from practice-based standards or lessons from successful practices to protect and promote health (Mpofu et al. 2015; Swisher 2010). For instance, adherence to religious teaching endorsed dietary guidelines for lower consumption of high-energy food, fat and saturated fats among Christian, Jewish and Muslim faith adherents is associated with their superior health and wellbeing compared to the general public (Eliasi and Dwyer 2002; Hill et al. 2006; McKenzie et al. 2014; Shatenstein and Ghadirian 1998). Religious adherents may accept derived health norms by degree, based on their real-world experience with the health activities and actions for them. 
Reference health norms. Reference health norms are aligned to community level health indicators or metrices such as control of communicable diseases, prevalence of non-communicable diseases, absence of contaminants to water and air quality, toxic food networks and presence of green zones (Andersen 2008; Mpofu et al. 2015). However, social segments existing within the broader community may elect to prioritize certain community health indicators to others (Brenner 2001; Mpofu et al. 2011; Mpofu et al. 2015). For instance, a religious community might prioritize non-medical health and wellbeing indicators (e.g., use naturalistic diets, spiritual health fellowships) whereas the general public may prioritize availability of bio-medical interventions and affiliation with health promotion clubs. Adherence to religious community reference norms may be health promotive (as in with prevention) (Hill et al. 2006; Islam and Johnson 2003) or health damaging (as with denying available proven treatments or cures) (Antai et al. 2009; Ha et al. 2014; Hawkins and Gillett 2015). A singular or targeted adherence to religious community values may carry the strength of clarity of health norms, inclusive of the processes and tools for actualizing those norms. However, strict adherence to religious community health standards also carries risk of harm from knowledge blind spots leading to skewed health norms

\section{Negotiated Health Norms}

People may distinguish between some of their health norms that they publicly endorse and which align with their faith beliefs, and other health norms that they frame privately guiding them in their personal health choices (Mpofu 2016; Mpofu et al. 2014). In that regard, religious adherents might also adopt negotiated health norms that draw from both religion and secular standards (as in Figure 1). Negotiated health norms are interpretive in their use by adherents of a religion to bridge religious and secular community health values (Fiori et al. 2006; Mpofu et al. 2014; Nicholson et al. 2010; Stetsenko and Arievitch 2004). For instance, the health activity of planned parenthood (a secular community standard) typically takes shape by use of contraception (which may be prohibited by a religious community). Religious adherents may adopt negotiated health norms to adopt both planned parenthood and naturalistic fertility control actions. However, others of the same religion may follow a derived health norm practice in which they adopt planned parenthood and fertility contraception believing their choices divinely given by a higher spiritual authority. In their private framing of health norms, religious adherents may take a position between permissible faith and secular health standards to best address their evolving health needs. Ultimately, negotiated health norms are privately framed, allowing for elective personal or best choice health norms.

\section{Elective Health Norms}

Elective health norms in their private framing allow for a sense of personal agency in self-determining one's health outcomes. Sense of personal agency in health activities and actions is associated with openness to adopt health practices not previously considered (Wang and Wang 2010). For instance, religious adherents who privately frame their health norms may choose to access public health services for some of their health-care needs (e.g., physical) rather than others (e.g., mental) for which they may adhere to faith-aligned wellbeing solutions (e.g., fasting, meditation, prayer). In other words, personal agency with privately framed health norms allows for "response-shift" in health norms and the means to enact them.

Response-shift theory (Schwartz et al. 2006) describes the specific mechanisms that explain the realignment of thoughts and/or behaviors with psycho-behavioral dissonance. A response-shift is adopting one or more of the following actions (a) a change in one's private framing or internal standards (i.e., personal scale recalibration); (b) a change in one's values (i.e., relative importance of the health norm evidence claims); and (c) re-defining value (i.e., health norm value re-conceptualization in the face of new evidence). For instance, early stage coping with a degenerative disease by an areligious adherent might use consolation religious texts to hold steady in one's faith in the gracious support 
from the higher spiritual authority. Later or terminal stage illness coping may shift to coping by surrendering mortality to the higher spiritual authority.

Privately framed health norms are person-centered and explain health actions close to a person's health-related quality of life. They are premised on individual choice or volition in health decision-making. Thus, in addition to religious community values, the personal choices of religious adherents might influence their priority health-related actions.

Religious adherents may result with weak health norms from a subtractive effect of competing religion and personal values. This would be the case when the religion community values are at odds with an adherent's personal values. For instance, a religion community value to preserve bodily integrity at burial may generate competing responses in adherents wanting to donate own body parts to serve human lives. As previously noted, religious adherents may have stronger health norms with adherence to a singular health value system (i.e., religious or personal-privately framed). Religious adherents also may result with stronger health norms from overlapping religion and personal health values through their mutual reinforcement, as when religious teachings for vegetarian diets also coincide with being a vegetarian. The evidence for competing or overlapping response effect is yet to be, formally documented. Nonetheless, holding to weak health norms diminishes commitment to engage in activities for wellbeing in the presence of preventive or curative health services.

\section{Implications for Public Health Services Partnerships with Faith Communities}

Public health promotion is a multi-sectorial enterprise involving community, state and federal government agencies. As previously, noted, religious communities are key partners in the sustenance and promotion of public health (Duff and Buckingham 2015; Gunderson and Cochrane 2012; Levin 2013; Olivier 2015). In their diversity, religious communities foster qualitatively different health value systems with variable effects on the well-being of the adherents. On the one hand, religious communities may predetermine priority health and wellbeing activities for the membership to seek to achieve. On the other hand, religious adherents may elect the specific health promotion and maintenance actions for wellbeing within the rules of the religious community (Hill et al. 2006; Shatenstein and Ghadirian 1998). Religious adherents also may subscribe to personal health norms, backgrounding faith-aligned interpretations of their health actions (Mpofu et al. 2011; Park 2005). A situation in which religion and personal health values are counter-influencing allows for a dialectical view of faith-oriented health norms as both social and individual, with neither completely explaining the other.

Although religious identity pre-sets the context of their health behaviors, adherents would differ to some degree in their interpretation of religion-aligned health actions (Mpofu et al. 2014; Fiori et al. 2006; Nicholson et al. 2010). This diversity in interpretive health norms provides for a window of opportunity for health promotion activities with religion adherents who may be open to adopt evidence informed health practices not currently engaged.

\section{Summary and Conclusions}

Religious communities likely precondition health norms of the adherents in ways important for public health promotion with the adherents. The adherents likely enact faith aligned social rules and priority activities for their health and wellbeing. People are likely to participate in public health programs aligned to their priority health norms. By implication, public health promotion initiatives with religious adherents should address faith community-oriented reference standards for credibility adoption. Religious adherents also likely construct personal health norms to guide their health service choices in a secular world. Moreover, some religious communities may be more accommodating of personal or interpretive health norms of adherents than others. The tendency to view adherents to a religion as a monolithic collective in their health norms is likely misplaced, and unproductive in public health promotion with religion adherents. Religious adherents likely would adopt public 
health initiatives aimed to best address their evolving health needs and that referenced their priority health norms.

Acknowledgments: This study was funded in part by a grant from the Eunice Kennedy Shriver National Institute of Child Health and Human Development, National Institutes of Health (R21 HD 061021; Elias Mpofu, PI). The content is solely the responsibility of the author and does not necessarily represent the official views of the Eunice Kennedy Shriver National Institute of Child Health \& Human Development or the National Institutes of Health.

Conflicts of Interest: The author declares no conflict of interest.

\section{References}

Allport, Gordon W., and Ross J. Michael. 1967. Personal religious orientation and prejudice. Journal of Personality and Social Psychology 5: 432-43. [CrossRef] [PubMed]

Andersen, Ronald Max. 2008. National health surveys and the behavioral model of health services use. Medical Care 46: 647-53. [CrossRef] [PubMed]

Antai, Diddy, Gebrenegus Ghilagaber, Sara Wedrén, Gloria Macassa, and Tahereh Moradi. 2009. Inequities in under-five mortality in Nigeria: Differentials by religious affiliation of the mother. Journal of Religion and Health 48: 290-304. [CrossRef] [PubMed]

Asser, Seth M., and Rita Swan. 1998. Child fatalities from religion-motivated neglect. Pediatrics 101: 625-29. [CrossRef] [PubMed]

Benjamins, Maureen R., Jenny Trinitapoli, and Christopher G. Ellison. 2006. Religious attendance, health maintenance beliefs, and mammography utilization: Findings from a nationwide survey of Presbyterian women. Journal for the Scientific Study of Religion 45: 597-607. [CrossRef]

Brenner, Louis. 2001. Controlling Knowledge: Religion, Power, and Schooling in a West African Muslim Society. Bloomington: Indiana University Press.

Bryan, Jennifer L., Sydnee H. Lucas, Michelle C. Quist, Mai-Ly N. Steers, Dawn W. Foster, Chelsie M. Young, and Qian Lu. 2016. God, can I tell you something? The effect of religious coping on the relationship between anxiety over emotional expression, anxiety, and depressive symptoms. Psychology of Religion and Spirituality 8: 46-53. [CrossRef] [PubMed]

Chopra, Deepak. 2012. God: A Story of Revelation. New York: HarperCollins.

Clements, Andrea D., and Anna V. Ermakova. 2012. Surrender to God and stress: A possible link between religiosity and health. Psychology of Religion and Spirituality 4: 93-107. [CrossRef]

Cohen, Adam B., Daniel E. Hall, Harold G. Koenig, and Keith G. Meador. 2005. Social versus individual motivation: Implications for normative definitions of religious orientation. Personality and Social Psychology Review 9: 48-61. [CrossRef] [PubMed]

Cuperman, Ronen. 2010. Does Our Perception of God Influence Our Perception of Subjectively "Sinful" Behaviours. Unpublished Ph.D. dissertation, University of Texas at Arlington, Arlington, USA.

Duff, Jean F., and Warren W. Buckingham. 2015. Strengthening of partnerships between the public sector and faith-based groups. The Lancet 386: 1786-94. [CrossRef]

Eliasi, Jennifer R., and Johanna T. Dwyer. 2002. Kosher and Halal: Religious observances affecting dietary intakes. Journal of the Academy of Nutrition and Dietetics 102: 911-13. [CrossRef]

Fiori, Katherine L., Edna E. Brown, Kai S. Cortina, and Toni C. Antonucci. 2006. Locus of control as a mediator of the relationship between religiosity and life satisfaction: Age, race, and gender differences. Mental Health, Heligion and Culture 9: 239-63. [CrossRef]

Ghaly, Mohamm. 2012. Religio-ethical discussions on organ donation among Muslims in Europe: An example of transnational Islamic bioethics. Medicine, Health Care and Philosophy 15: 207-20. [CrossRef] [PubMed]

Graham, Jesse, and Jonathan Haidt. 2010. Beyond beliefs: Religions bind individuals into moral communities. Personality and Social Psychology Review 14: 140-50. [CrossRef] [PubMed]

Gunderson, Gary R., and James R. Cochrane. 2012. Religion and the Health of the Public: Shifting the Paradigm. New York: Palgrave McMillan.

Ha, Wei, Peter Salama, Stanley Gwavuya, and Chifundo Kanjala. 2014. Is religion the forgotten variable in maternal and child health? Evidence from Zimbabwe. Social Science E Medicine 118: 80-88. 
Hawkins, Stacey A., and James Gillett. 2015. Reconstructing Aboriginal Identity and the Meaning of the Body in Blood Donation Decisions. Journal of Religion and Health 54: 1286-301. [CrossRef] [PubMed]

Hill, Terrence D., Amy M. Burdette, Christopher G. Ellison, and Marc A. Musick. 2006. Religious attendance and the health behaviors of Texas adults. Preventive Medicine 42: 309-12. [CrossRef] [PubMed]

Hoffman, Jay. 2006. Norms for Fitness, Performance, and Health. Champaign, IL: Human Kinetics.

Islam, Sondos M. S., and Carl Anderson Johnson. 2003. Correlates of smoking behavior among Muslim Arab-American adolescents. Ethnicity E Health 8: 319-37.

Jackson, Brenda R., and Cindy S. Bergeman. 2011. How does religiosity enhance well-being? The role of perceived control. Psychology of Religion and Spirituality 3: 149-61. [CrossRef] [PubMed]

Johnson, Kathryn A., Morris A. Okun, and Adam B. Cohen. 2015. The mind of the Lord: Measuring authoritarian and benevolent God representations. Psychology of Religion and Spirituality 7: 227-38. [CrossRef]

Karam, Azza, Julie Clague, Katherine Marshall, and Jill Olivier. 2015. The view from above: Faith and health. The Lancet 386: e22-24. [CrossRef]

Karmon, Amnon. 2007. Institutional organization of knowledge: The missing link in educational discourse. Teachers College Record 109: 603-34.

Kline, Susan L. 2011. Communicating spirituality in healthcare: A case study on the role of identity in religious health testimonies. Journal of Applied Communication Research 39: 334-51. [CrossRef]

Koenig, Harold G., David B. Larson, and Susan S. Larson. 2001. Religion and coping with serious medical illness. Annals of Pharmacotherapy 35: 352-59. [CrossRef] [PubMed]

Kremer, Heidemarie, Gail Ironson, Nicoleta de Deugd, and Monica Mangra. 2014. The association between compassionate love and spiritual coping with trauma in men and women living with HIV. Religions 5: 1050-61. [CrossRef]

Kuuti, Kari. 1996. Activity theory as a potential framework for human-computer research. In Context and Consciousness. Edited by Bennie A. Nardi. Cambridge: MIT Press, pp. 17-44.

Levin, Jeff. 2013. Engaging the faith community for public health advocacy: An agenda for the Surgeon General. Journal of Religion and Health 52: 368-85. [CrossRef] [PubMed]

Masters, Kevin S., and Glen I. Spielmans. 2007. Prayer and health: Review, meta-analysis, and research agenda. Journal of Behavioral Medicine 30: 329-38. [CrossRef] [PubMed]

McCullough, Michael E., and Brian L. B. Willoughby. 2009. Religion, self-regulation, and self-control: Associations, explanations, and implications. Psychological Bulletin 135: 69-93. [CrossRef] [PubMed]

McKenzie, Monica M., Naomi Modeste, Helen Hopp Marshak, and Colwick Wilson. 2014. Religious involvement and health-related behaviors among Black Seventh-Day Adventists in Canada. Health Promotion Practice 16: 264-79. [CrossRef] [PubMed]

Mpofu, Elias. 2016. Follower-centric influences on sexual decision making in a Pentecostal church faith community. Religions 7: 66. [CrossRef]

Mpofu, Elias, Tinashe Moira Dune, Denise Dion Hallfors, John Mapfumo, Magen Mutepfa, and James January. 2011. Apostolic faith organization contexts for health and wellbeing in women and children. Ethnicity and Health 13: 551-66. [CrossRef] [PubMed]

Mpofu, Elias, Fidelis Nkomazana, Jabulani A. Muchado, Lovemore Togarasei, and Jeffrey Bart Bingenheimer. 2014. Faith and HIV prevention: The conceptual framing of HIV prevention among Pentecostal Batswana teenagers. BMC Public Health 14: 225. [CrossRef] [PubMed]

Mpofu, Elias, Mary Lam, Ngonidzashe Mpofu, Ebonee Johnson, and Doug W. Evans. 2015. Monitoring and evaluation of community oriented health services. In Community Oriented Health Services: Practices across Disciplines. Edited by Elias Mpofu. New York: Springer, pp. 117-33.

Mumby, Dennis K. 1987. The political function of narrative in organizations. Communications Monographs 54: 113-27. [CrossRef]

Muramoto, Osamu. 1999. Bioethics of the refusal of blood by Jehovah's Witnesses: Part 3. A proposal for a do not-ask-do not-tell policy. Journal of Medical Ethics 25: 463-68. [CrossRef] [PubMed]

Nicholson, Amanda, Richard Rose, and Martin Bobak. 2010. Associations between different dimensions of religious involvement and self-rated health in diverse European populations. Health Psychology 29: 227-35. [CrossRef] [PubMed] 
Olivier, Jill. 2015. Religion at the intersection of development and public health in development contexts: From advocacy about faith-based organizations to systems thinking. In The Routledge Handbook of Religions and Global Development. Edited by Emma Tomalin. London: Routledge, pp. 346-58.

Pargament, Kenneth I., Harold G. Koenig, Nalini Tarakeshwar, and June Hahn. 2004. Religious coping methods as predictors of psychological, physical and spiritual outcomes among medically ill elderly patients: A two-year longitudinal study. Journal of Health Psychology 9: 713-30. [CrossRef] [PubMed]

Park, Crystal L. 2005. Religion as a meaningmaking framework in coping with life stress. Journal of Social Issues 61: 707-29. [CrossRef]

Pender, Nola J., and Albert R. Pender. 1985. Attitudes, subjective norms, and intentions to engage in health behaviors. Nursing Research 35: 15-18. [CrossRef]

Pietkiewicz, Igor J., and Dawid Bachryj. 2016. Help-seeking attitudes and coping strategies among Roman Catholic secular clergy. Psychology of Religion and Spirituality 8: 13-24. [CrossRef]

Ray, Darrel W. 2009. The God Virus: How Religion Infects Our Lives and Culture. Bonn: IPC Press.

Regnerus, Mark D. 2003. Religion and positive adolescent outcomes: A review of research and theory. Review of Religious Research 44: 394-413. [CrossRef]

Roth, Wolff-Michael, and Yew-Jin Lee. 2007. Vygotsky's neglected legacy: Cultural-historical activity theory. Review of educational research 77: 186-232. [CrossRef]

Shariff, Azim. F. and Ara Norenzayan. 2011. Mean gods make good people: Different views of God predict cheating behavior. The International Journal for the Psychology of Religion 21: 85-96.

Schwartz, Carolyn E., Rita Bode, Nicholas Repucci, Janine Becker, Mirjam A. G. Sprangers, and Peter M. Fayers. 2006. The clinical significance of adaptation to changing health: A meta-analysis of response shift. Quality of Life Research 15: 1533-50. [CrossRef] [PubMed]

Shatenstein, Bryna, and Parviz Ghadirian. 1998. Influences on diet, health behaviours and their outcome in select ethnocultural and religious groups. Nutrition 14: 223-30. [CrossRef]

Sherman, Steven J., and Larry Gorkin. 1980. Attitude bolstering when behavior is inconsistent with central attitudes. Journal of Experimental Social Psychology 16: 388-403. [CrossRef]

Skitka, Linda J., Christopher W. Bauman, and Edward G. Sargis. 2005. Moral conviction: Another contributor to attitude strength or something more? Journal of Personality and Social Psychology 88: 895-917. [CrossRef] [PubMed]

Stetsenko, Anna, and Igor M. Arievitch. 2004. The self in cultural-historical activity theory: Reclaiming the unity of social and individual dimensions of human development. Theory \& Psychology 14: 475-503.

Swisher, Anne K. 2010. Practice-based evidence. Cardiopulmonary Physical Therapy Journal 21: 4. [PubMed]

Tomkins, Andrew M., Jean Duff, Atallah Fitzgibbon, Azza Karam, Edward J. Mills, Keith Munnings, Sally Smith, Shreelata Rao Seshadri, Avraham Steinberg, Robert Vitillo, and et al. 2015. Controversies in faith and health care. The Lancet 386: 1776-85. [CrossRef]

Wang, Mingxu, and Xueliang Wang. 2010. Organ donation by capital prisoners in China: Reflections in Confucian ethics. Journal of Medicine and Philosophy 35: 197-212. [CrossRef] [PubMed]

Wesselmann, Eric D., Laura E. VanderDrift, and Christopher R. Agnew. 2016. Religious commitment: An interdependence approach. Psychology of Religion and Spirituality 8: 35-45. [CrossRef]

(C) 2018 by the author. Licensee MDPI, Basel, Switzerland. This article is an open access article distributed under the terms and conditions of the Creative Commons Attribution (CC BY) license (http://creativecommons.org/licenses/by/4.0/). 